\title{
ALUA JO PATUIK PROSES KREATIF SIMARANTANG KARANG MANIH EFYUHARDI
}

\author{
Fani Dilasari \\ Program Pascasarjana \\ Institut Seni Indonesia Surakarta \\ JI. Ki Hadjar Dewantara No. 19 Kentingan, Jebres, Surakarta, 57126 \\ Email: Fanidilasari@gmail.com
}

\begin{abstract}
ABSTRAK
Keindahan intelektual adalah pemikiran yang indah berdasarkan ilmu pengetahuan. Keindahan dalam arti estetik murni menyangkut pengalaman estetis dari seseorang dalam hubungannya dengan segala sesuatu yang dicerapnya. Pengetahuan tradisi yang dimiliki Efyuhardi sebagai putra daerah Pariaman, serta ilmu teater yang didapatkannya melalui pendidikan Seni Teater menjadikan karya Simarantang Karang Manih menarik untuk ditinjau dari proses kreatif. Tindakan kreatif Efyuhardi mengimplementasi budaya Pariaman ke dalam bentuk Simarantang diidentifikasi sebagai Tuo Randai. ${ }^{1}$ Tindakan kreatif Efyuhardi pada penciptaan Simarantang Karang Manih bernaung pada estetika Minangkabau yaitu Alua jo Patuik.
\end{abstract}

Kata kunci: Simarantang Karang Manih, Efyuhardi, Proses Kreatif dan Alua jo Patuik.

\begin{abstract}
ABSTRAK
Intellectual beauty is the beautiful thinking based on science. Beauty in a pure aesthetic sense concerns with the aesthetic experience of a person in relation to everything he perceives. Traditional knowledge belongs to Efyuhardi as a son of the Pariaman region as well as the theater knowledge he got made the work of Simarantang Karang Manih interesting to be reviewed in case of its creative process. Efyuhardi's Creative action in implementing the Pariaman culture in the form of Simarantang is identified as Tuo Randai. Efyuhardi's creative action in the creation of Simarantang Karang Manih is based on the Minangkabau aesthetic, namely Alua jo Patuik.
\end{abstract}

Keywords: Simarantang Karang Manih, Efyuhardi, Creative Process and Alua jo Patuik.

\section{A. Pengantar}

Salah satu teater rakyat yang saat ini masih hidup di tengah masyarakat Minangkabau, khususnya di Pariaman adalah Simarantang. Bagi masyarakat Pariaman Simarantang berperan sebagai hiburan dalam kegiatan upacara dan adat. Simarantang diperlakukan khusus dalam pelaksanaan pertunjukannya sebagai pamenan anak nagari ${ }^{2}$. Simarantang yang mengusung kekhasannya dalam kaidah-kaidah estetika adalah produk budaya dari kreativitas seniman di tengah masyarakat. Kreativitas seorang seniman merupakan identitas dan proses simbolis bagi masyarakatnya. Kekhasan ini dapat dilihat dari tindak kreatif Efyuhardi dalam proses penciptaan Simarantang Karang Manih.

Bersama sanggar Alam Takambang (ABG) Maimbau yang dibentuknya pada tahun 1999, Efyuhardi eksis dan pernah menjuarai Festival Randai se-Sumatera Barat (Efyuhardi, wawancara 1 Agustus
2015). Berbeda dari grup Simarantang lain yang hanya memainkan satu lakon Simarantang yang sama di setiap pertunjukannya serta menjadikan judul naskah itu sebagai nama dari grup Simarantangnya, maka sanggar Alam Takambang (ABG) Maimbau lebih variatif dalam mengusung lakon pertunjukan Simarantang. Sanggar Alam Takambang Maimbau menjadi ruang edukasi seni dan budaya bagi anggotanya yang rata-rata kaum pelajar. Melalui Simarantang terbinalah pendidikan karakter dengan carito $^{3}$ yang mengusung nilai-nilai budaya Minangkabau.

Efyuhardi mengorganisir terwujudnya sebuah Simarantang dari pelatihan hingga menjadi sebuah pertunjukan. Melalui pengetahuan dan kepandaian lebih yang dimiliki, Efyuhardi mampu dalam penciptaan carito, membentuk gerak legaran, membentuk pamain carito $^{4}$ dan komposisi karawitan. Efyuhardi bertanggung jawab penuh terhadap penciptaan Simarantang. Hal tersebut dapat dilihat pada proses 


\section{GE[AR Jumal Sori Bublya}

kreatif Simarantang Karang Manih. Berdasarkan kemampuan tersebut Efyuhardi disebut Tuo Randai. Pertunjukan Simarantang Karang Manih adalah karya terbaru Efyuhardi menjelang akhir tahun 2015 yang dapat mewakili tindak kreatif Efyuhardi dalam garapangarapan sebelumnya yang berbasis materi tradisi. Pertunjukan Simarantang Karang Manih hadir sebagai salah satu pengisi acara pada alek nagari di kanagarian $^{5}$ Sicincin dan pertunjukan ini mendapat respon meriah dari penontonnya. Carito Karang Manih mengangkat tentang kehidupan seorang gadis yatim piatu yang tinggal di rumah pamannya. Ia mendapatkan perlakuan buruk dari istri dan anak lakilaki pamannya. Ketabahan Karang Manih dalam menghadapi problema hidupnya menjadi gambaran dalam penceritaan pertunjukan ini. Menariknya, seluruh pamain carito ${ }^{6}$ dalam garapan Simarantang Karang Manih adalah anak-anak.

Kreativitas Efyuhardi mengimplementasi budaya Pariaman ke dalam bentuk Simarantang diidentifikasi sebagai Tuo Randai. Pemikirannya terhadap aspek-aspek Simarantang dan realitas sosial yang dihadapi tokoh dalam carito adalah dualisme yang sejalan. Esensi dasar dari kreativitasnya yakni tiga spirit dari randai ${ }^{7}$, indang ${ }^{8}$ dan luambe $k^{9}$.

Tiga hal tersebut sangat tampak pada Simarantang Karang Manih. Batasan permasalahan pada tulisan ini adalah bagaimana etnoestetika Simarantang Karang Manih Efyuhardi dan bagaimana tindakan kreatif Efyuhardii dalam penciptaan Simarantang Karang Manih. Adapun permasalahan tersebut memiliki tujuan menganalisis tindak kreatif dalam penciptaan Simarantang Karang Manih yang merupakan suatu usaha memahami kekhasan Simarantang secara khusus ataupun umum. Manfaat dari tulisan ini diharapkan dapat menjadi bahan analisa dalam memahami etnoestetika dalam penciptaan Simarantang, khususnya Simarantang Karang Manih dan dapat menambah pengetahuan untuk mengembangkan Simarantang di Pariaman. Penulisan yang digunakan adalah deskriptif analisis dengan kerangka konseptual yaitu kreativitas, etnodramaturgi dan etnoestetika. Pendekatan konseptual tersebut didasari penelitian secara kualitatif terhadap proses kreatif Simarantang Karang Manih Efyuhardi.

\section{B. Pembahasan}

\section{Definisi Simarantang}

Efyuhardi memiliki dua pemahaman mengenai asal kata Simarantang. Pertama, Simarantang adalah nama seorang pedagang keliling yang menciptakan irama-irama sendiri dalam menjajakan dagangannya guna menarik hati pembeli. Irama yang dinyanyikan berulang-ulang dan menjadi ciri khas, sehingga dikenal dengan dendang Simarantang dan kisahnya diangkat menjadi cerita Simarantang. Kedua, Simarantang secara etimologi berasal dari dua suku kata yakni Si dan Marantang. Kata Si merujuk pada benda yakni bisa saja orang, panggilan atau pelaku. Marantang merupakan kata kerja rentang setelah diberi imbuhan "me" yakni merentang. Simarantang adalah pelaku yang merentangkan peristiwa, menjabarkan kisah, memanjangkan atau mengulurkan cerita sehingga sampai ke masyarakat luas. Pelaku yang dimaksud bisa saja orang, panggilan ataupun kelompok yang merentangkan kisah (wawancara, 30 Juli 2016).

Pemahaman terhadap istilah Simarantang berhubungan dengan istilah Randai yang dipahami masyarakat Minangkabau di wilayah lain. Secara bentuk antara Simarantang dan Randai adalah sama, sementara bagi masyarakat Pariaman merupakan penamaan bentuk yang berbeda. Di Pariaman, istilah randai merupakan bentuk tari dengan pola lingkaran, sementara Simarantang merupakan bentuk teater yang dengan pola lingkaran yang memiliki pengembangan peristiwa yang di bangun oleh pamain carito ${ }^{10}$.

Herizal mengungkapkan bahwa pada mulanya Simarantang adalah salah satu pamenan anak nagar ${ }^{11}$ berbentuk seni tari, di dalamnya terdapat langkah silat dan gerakan seperti pencak, memainkannya berkeliling dalam lingkaran, dan jumlah pemainnya 6 orang anak randai $i^{2}$ bahkan lebih. Randai inilah cikal bakal lahirnya Simarantang. Randai kemudian membawakan kaba dan dikembangkan layaknya sebuah teater rakyat yang disebut Simarantang (wawancara, 5 Juni 2015).

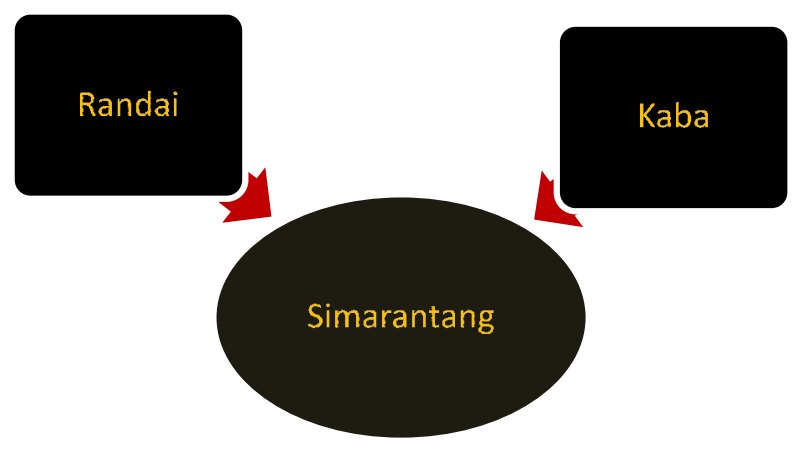

Kerangka akulturasi randai dengan kaba (ilustrasi: Fani DS). 


\section{Unsur-unsur Simarantang a. Kaba}

Sumber carito pertunjukan Simarantang adalah kaba. Kaba merupakan karya sastra Minangkabau berupa gurindam yang berisikan hikayat, cerita rakyat, legenda, dan lainnya. Kaba dapat berbentuk tutur atau tulisan. Bakaba sering disebut juga bacarito atau dapat diartikan berkabar. Panghoeloe dalam bukunya Kaluak Randai menyebutkan asal kata dan pengertian kaba sebagai berikut.

"Kaba" dipandang dari sudut asal katanya dari Bahasa Arab "khabarun", artinya berita atau warta. "Khabarun" yang diucapkan "khabar" dalam Bahasa Indonesia berubah lamakelamaan jadi "kabar" dan dalam Bahasa minang diucapkan "kaba". Tetapi pengertian "kaba" yang dimaksud dalam naskah ini lebih luas dari makna "khabar" menurut logat Arab. Jauh sebelum kata "kaba" dimasukan ke dalam pembedaharaan kamus Minangkabau, ujud yang terkandung di dalamnya telah tersimpul carito (dari kata sansekerta "ceritera") yang dimaksud petikan suatu kejadian (1980: 7).

Pada awalnya tukang kaba identik dengan tukang dendang, sebab kaba awalnya dituturkan melalui nyanyian dengan irama-irama khas. Hal ini bertujuan menyampaikan nilai-nilai pendidikan, adat dan agama agar menarik untuk didengar oleh masyarakat. Kaba menjadi sastra lisan yang terus berkembang menjadi seni pertunjukan yang disertai alat karawitan seperti basijobang, basaluang, barabab dan lain-lain.

Perkembangan selanjutnya kaba di dramatisasi dan diwujudkan menjadi teater rakyat yang disebut Simarantang. Kaba dalam Simarantang akan diantarkan melalui teaterikal dialog oleh pamain carito dan melalui narasi cerita dengan dendang oleh tukang dendang. Dua hal ini terjalin menjadi kesatuan penceritaan dan gerak dalam legaran Simarantang.

\section{b. Karawitan}

Pertunjukan Simarantang dilengkapi sekelompok pemain karawitan yang menjadi bagian dari pertunjukan tersebut. Alat karawitan yang digunakan dalam pertunjukan tersebut di antaranya Bansi, Saluang, Gandang, Talempong, Sarunai dan lain-lain. Di antara pemain karawitan ada seorang tukang dendang yang berfungsi untuk menyampaikan kaba melalui dendang. Dendang adalah seni vokal di Minangkabau berupa gurindam. Kaba yang bukan berupa dialog akan dinyanyikan. Gurindam ini menjadi penghantar cerita sebelum masuk pada dialog awal pamain carito setiap satu legaran. Secara etimologi dendang berasal dari kata den yang berarti saya dan kata dang berarti dengung atau bersuara.

\section{c. Gerak}

Gerak Simarantang berasal dari gerak silek, tari dan tapuak yang disertai goreh sebagai aba-aba sehingga menjadi kesatuan dalam legaran. Adapun penjelasan lebih rinci sebagai berikut.

1) Goreh

Kerumunan orang yang berbaris melingkar dalam legaran yang disebut anak randai. Anak randai biasanya berjumlah genap yang terdiri dari enam, delapan, sepuluh, atau lebih sesuai dengan kebutuhan dan kapasitas ruang pertunjukan. Anak Randai bergerak mengitari formasi lingkaran yang dipandu aba-aba yang disebut goreh.

Tukang goreh berfungsi sebagai pemberi aba-aba bagi anak randai di dalam legaran dengan mengeluarkan vokal atau bersuara. Goreh adalah aba-aba dalam setiap gerak balega (berputar) dalam legaran. Anak randai dalam legaran memainkan pola yang sama, baik itu pola lantai dan pola pukulan dengan intruksi tukang goreh dengan berteriak “Apzzz!! Hep, tah, tih, yaa!!

2) Silek

Silek merupakan cara mempertahankan diri dari se-rangan lawan. Tradisi ilmu silek merupakan warisan leluhur yang diwariskan dari satu generasi ke ge-nerasi berikutnya secara turun te-murun. Pemimpin dalam suatu perguruan silek atau bisa dikatakan yang ahli dalam silek disebut Tuo Silek. Silek adalah akronim kata dari si liek (si lincah atau orang yang pintar mengelak). Dalam budaya Minangkabau, seorang pandeka silek di samping mahir dalam ilmu beladiri, juga mahir silek lidah ${ }^{13}$. Artinya seorang pandeka silek juga harus pintar dalam hal diplomasi.

Silek sebagai permainan disebut pencak dan sebagai seni bela diri dinamakan silek, pencak sebagai permainan merupakan salah satu bagian awal mempelajari gerakan silek. Pencak silat ini disebut dengan bungo silek. Bungo silek berarti bunga atau kembang silat yang menampilkan keindahan dari gerakan silat. Bungo silek inilah yang kemudian dikembangkan menjadi gerakan dalam legaran. 


\section{GEEAR Jumal sai isubya}

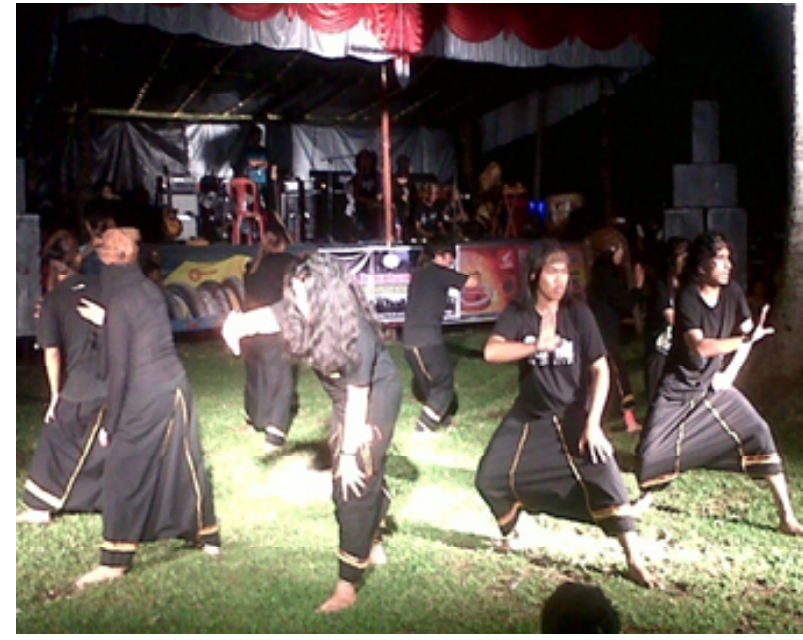

Gambar Salah satu gerakan adopsi bungo silek dalam legaran (foto: Fani DS).

3) Tari

Gerakan tari dalam pertunjukan Simarantang adopsi dari tari galombang dan tari bagurau. Gerakan seperti gelombang air laut maju dan mundur dalam legaran. Simarantang sangat identik dengan gerakan gelombang yang dibentuk dengan pola lantai melingkar dan para anak randai biasanya berjalan balega berlawanan arah jarum jam.

Secara keseluruhan gerakan tari pada pertunjukan Simarantang memakai sistem rampak. Sistem rampak pada gerakan tari tidak dilakukan secara menyeluruh pada satu bagian, tetapi memiliki bentuk yang terpisah. Hal ini disebabkan karena gerakan dalam Simarantang harus disesuaikan dengan dendang yang merujuk pada suasan carito Simarantang. Jika suasana carito Simarantang gembira dendang yang dilagukan adalah dendang gembira, maka gerakan tari yang dibentuk pun berupa gerak tari riang bahkan ditambahkan dengan tari bagurau (suka ria). Sebaliknya jika suasana sedih akan dilagukan dengan dendang ratok, maka gerak tari berupa gerakan lebih sederhana dan pelan.

4) Tapuak

Tapuak artinya dalam bahasa Indonesia adalah tepuk. Setelah dendang selesai, pemain legaran selalu menutupnya dengan tapuak. Ada dua tapuak dalam legaran Simarantang, yakni tapuak tangan dan tapuak galembong. Setiap tapuak memiliki ragam tingkah ${ }^{14}$. Dahulunya dalam legaran tidak ada tapuak galembong namun perkembangan kreatifitas agar pertunjukan lebih atraktif maka dihadirkan tapuak galembong ${ }^{15}$.
Galembong merupakan celana khusus yang dipakai dalam pertunjukan Simarantang. Galembong berbentuk seperti celana silat, tetapi mempunyai bagian pisak ${ }^{16}$ yang besar. Anak randai dalam pertunjukan Simarantang dengan gerak tapuak dan goreh dapat berfungsi sebagai pembentuk musik internal. Anak randai memukul bagian bawah celana untuk menghasilkan bunyi yang teratur sehingga menambah kemeriahan pertunjukan tersebut.

\section{Kesenimanan Efyuardi}

Etnis Minangkabau membangun peradaban di atas pengetahuan dan pendidikan kultural yang lekat dengan ideologi Alam takambang jadi guru. Idiologi tersebut dijadikan konsep berfikir dan berprilaku, bahwasannya orang Minangkabau mesti belajar dari alam dan mempelajari apapun yang ada disekitarnya. Sebab alam adalah tempat hidup, tumbuh, berkembang dan berbudaya. Alam adalah pusat dalam proses pendidikan di Minangkabau. Alam takambang jadi guru melekat pada diri seorang seniman Minangkabau. Ideologi ini ketat mempengaruhi krativitas seniman dalam penciptaan karya seninya. Soedarsono juga menyebutkan interaksi antara manusia dan alam sekitar banyak hubungannya dengan penciptaan karya seni, baik dari sisi motivasi penciptaan maupun hasil kemudian (2006:14)

Efyuhardi lahir di Pariaman pada 7 November tahun 1974. la merupakan anak dari Muzarudin dan Darwis. Muzarudin merupakan lulusan jurusan karawitan Akademi Seni Karawitan Padangpanjang. Efyuardi menyatakan bahwa darah seni turun dari Muzarudin (wawancara, 1 September 2015). Muzarudin yang mengawali karirnya menjadi pegawai negri sipil sebagai guru SD di daerah Maninjau Sumatera Barat. Selanjutnya Muzarudin pindah tugas di Taman Budaya Padang yang kemudian hingga akhir pensiun dengan jabatan kasi di Dinas Pendidikan Provinsi Sumatera Barat. Sementara ibunya berprofesi sebagai ibu rumah tangga tamatan SD.

Efyuardi kecil lekat dengan beragam alat musik tradisional Minangkabau milik ayahnya. Kesenangan terhadap kesenian tradisional Minangkabau dibentuk oleh lingkungan keluarganya terutama ayahnya. Beragam pengetahuan mengenai kesenian tradisi ia peroleh dari apa yang ia lihat, rasakan dan serap dari habitus alam Minangkabau. Pendidikan tradisional Minangkabau adalah pendidikan informal yang mencakup pada ilmu pengetahuan kulturalnya. Beberapa sentra basis yang di lalui oleh Efyuardi adalah sebagai berikut. 


\section{a. Pendidikan sasaran dan surau}

Sasaran adalah tempat dimana pandeka silek melakukan latihan silek. Kebanyakan silek tuo menempatkan surau sebagai tempat latihannya. Surau adalah salah satu basis dari pendidikan di Minangkabau, jauh sebelum adanya pendidikan formal. Surau merujuk pada bangunan tempat ibadah umat Islam. Fungsinya hampir sama dengan masjid yakni sebagai pusat kegiatan keagamaan masyarakat dan pendidikan dasar keislaman. Akan tetapi, karena bangunannya relatif lebih kecil dari masjid, surau biasanya tidak digunakan untuk pelaksanaan salat Jumat dan salat led.

Di Minangkabau, surau kebanyakan lebih dikhususkan sebagai lembaga pendidikan dikarenakan letaknya yang berdampingan dengan masjid. Istilah surau sudah dikenal di Minangkabau jauh sebelum kedatangan Islam. Efyuhardi menyebutkan setelah Islam masuk ke Minangkabau, silek digunakan se-bagai sarana dakwah dan syi'ar agama Islam, hingga saat ini. Ajaran dalam silek lebih banyak dipadukan dengan ajaran tauhid dan syari'at Islam (wawancara, 16 Agustus 2015). Silek adalah cara mendekatkan diri kepada alam dan kepada Allah sebagai sang pencipta, dengan sesama manusia dan alam sekitar. Proses pendidikan silek, sejak dahulunya sasaran silek yang ada indentik dengan surau. Surau tempat mengaji agama, disertai dengan sasaran silek berdiri. Bia-sa-nya selepas Magrib, pemuda Minang belajar dan mengaji ilmu agama Islam. Jelang tengah malam mereka turun ke sasaran yang ada di halaman surau untuk belajar seni bela diri silek.

\section{b. Maota lapau}

Maota adalah kata dari Bahasa Minangkabau yang artinya perbincangan santai atau ngobrolngobrol. Sementara istilah lapau artinya kedai kopi rakyat. Tempat ini biasanya dikunjungi oleh para lelaki Minangkabau yang bertemu untuk memperbincangkan berbagai hal sambil menikmati minuman hangat seperti kopi, teh atau minuman atau makanan lainnya. Maota dapat mencerminkan kebiasaan berbudaya lisan. Minangkabau dikenal dengan suku bangsa berbudaya tutur atau lisan menjadikan lapau sebagai tempat maota. Lapau menjadi ranah pergaulan yang juga tidak boleh dilewatkan oleh laki-laki Minangkabau, sebab lapau merupakan tempat berkumpulnya semua kalangan memperbincangkan suatu masalah baik pribadi maupun umum yang bisa di tarik pengetahuan dan pengalamannya. Efyuhardi menyebutkan bahwa berbagai hal yang ia dapati dan temui di lapau. Lapau adalah bagian realitas sosial bagi laki-laki Minangkabau, meski tak semua yang ada di lapau adalah suatu yang bisa dipakai, namun dapat dijadikan pengalaman agar terhindar dari hal yang berkonotasi negatif (wawancara, 1 September 2015).

\section{c.Pendidikan Formal dan Teater Modern}

Efyuardi telah bermain Simarantang sejak ia duduk di bangku SD pada tahun 1982. la bersekolah di SD Kampung Guci Kecamatan Dua Kali Sebelas Enam Lingkung Kabupaten Padang Pariaman Provinsi Sumatera Barat. Selain itu ia juga sering di ajak ayahnya menyaksikan acara-acara adat dan keagamaan yang meghadirkan seni budaya seperti tari indang, salawaik dulang dan seni budaya Pariaman lainnya.

Pada tahun 1988 Efyuardi melanjutkan pendidikan sekolah menengah di SMP Pakandangan dari rayon SD sebelumnya. Pada masa ini ia mulai menggemari drama dan sering melakukan pentas di sekolahnya. Efyuardi di dukung oleh guru seni budaya dan disarankan agar melanjutkan sekolah menengah umum di SMKI (Sekolah Menengah Karawitan Indonesia) di kota Padang pada tahun 1990 sampai 1994. Empat masa pendidikan di SMKI dengan mengambil minat teater menambah pengetahuanya pada seni teater baik itu teater tradisi maupun teater Barat. Namun Efyuardi lebih fokus pada teater tradisi Minangkabau khususnya Simarantang yang diminati sedari kecil. Hal ini mendorong Efyuardi untuk melanjutkan studi seni teater di Institut Seni Indonesia Yogyakarta dan pendidikan terakhir Efyuhardi merupakan Magister Penciptaan Seni di Institut Seni Indonesia Surakarta.

\section{d. Tuo Randai Sanggar Alam Takambang Maimbau}

Tuo Randai secara etimologi berasal dari bahasa Minangkabau yang terdiri dari dua suku kata, yaitu tuo berarti tua dan randai yang berarti kesenian randai. Tuo Randai adalah orang yang dituakan, karena memiliki pengetahuan dan kemampuan lebih dalam memimpin, mengelola, dan bertanggung jawab serta berperan penting dalam proses kreatif randai. Dahrizal menyebutkan Tuo Randai adalah pemimpin atau yang dituakan dalam grup Simarantang, sebab memiliki pengetahuan dan kepandaian lebih dalam mengatur adegan, mengatur musik dan seluruh wilayah artistik dalam permainan Randai. (wawancara, 28 Agustus 2015) 


\section{GEEAR Jumal Sari iuduya}

Adapun penyebutan lain untuk Tuo Randai dijelaskan Harun, bahwa menurut peran dalam sebuah randai ditentukan oleh pangka tuo randai, karena dialah yang memilih setiap karakter dan kemampuan bersilat setiap pemainnya. Pemeran utama misalnya haruslah orang yang memiliki vocal yang lantang dan mantap. Dia haruslah seorang pendekar yang mahir balabek, gerak khas pesilat, pandangan mata dari seluruh geraknya memperlihatkan kewaspadaan (Chairul Harun, 1992:112).

Tuo Randai dan pangka tuo adalah sama. bahkan jika dikaitkan dengan pengetahuan teater barat, bahwa peran Tuo Randai tak jauh berbeda dengan sistem kerja sutradara. Dalam pertemuan teater di Bandungan, Ambarawa tahun 1977, telah dirumuskan bahwa "seorang sutradara (director) sebagai seorang seniman teater yang mewujudkan naskah (visualisasi naskah) secara menyeluruh ke dalam kenyataan teater'. Sebagai seorang seniman teater ia dituntut kadar pengetahuannya tentang:

1) Aspek kultural: masalah-masalah kebudayaan pada umumnya;

2) Aspek artistik: menguasai masalah kesenian pada umumnya. Mempunyai cita rasa, kepekaan, keterbukaan. la harus bisa mengembangkan kreatifitas dan orisinalitasnya dengan menggunakan tiga penggerak kreativitas (kemauan, imajinasi dan perasan)

3) Aspek teateral: yang dimaksud adalah pengetahuan tentang pentas. Pentas sebagai wadah bagi peristiwa kehidupan manusia yang diwujudkan dalam naskah lakon; dan

4) Aspek literer (aspek sastra): yaitu menguasai masalah kesusastraan pada umumnya (prosa, puisi, drama) dan masalah-masalah bidang kesusastraan pada umumnya (teori sastra, sejarah sastra, kritik sastra), serta apresiasi sastra dan drama atau teater (Satoto, 2012:55).

Efyuhardi tergolong Tuo Randai baru, adalah penggerak lahirnya sanggar-sanggar Simarantang lain di Pariaman dengan Sanggar Alam Takambang Maimbau sebagai induk yang menetaskannya. Keberadaan Efyuhardi ini diakui karna kurangnya regenerasi dari sanggar-sanggar yang di bentuk oleh seniman tradisi dahulunya. Tak jarang sanggar atau kelompok Simarantang yang pernah ada di Pariaman sudah tinggal nama dan tidak aktif.

Berkreativitas dalam garapan Simarantang adalah pilihan Efyuhardi, meski berlatar belakang pendidikan sarjana teater yang juga mengulas ilmuilmu teater Barat. Hal ini didasari pada kecintaan seni tradisi. Keilmuan seni teater yang diterima di jenjang pendidikan dijadikan khasanah kreativitas dalam menata seni tradisi, membangun, mengembangkan dan mengkreasikannya agar tak lapuk di makan zaman.

\section{Analisis Tindakan Kreatif Efyuhardi dalam Penciptaan Simarantang Karang Manih.}

Simarantang hidup dalam ikatan tradisi Minangkabau yang sesuai dengan landasan Adat Basandi Syarak, Syarak Basandi Kitabullah. Kearifan lokal Minangkabau dapat diserap melalui kreativitas estetis yang terdapat pada Simarantang. Prinsip Kreativitas juga terdapat dalam pepatah Minangkabau yakni.

\author{
Usang usang diparbaharui \\ Lapuak-lapuak dikajangi \\ Nan elok di pakai \\ Kok singkek diuleh \\ Panjang minta dikarek \\ 41). \\ Terjemahan. \\ Yang telah usang diperbaharui \\ Yang lapuk di perbaiki \\ Yang baik dipakai \\ Yang buruk di buang \\ Jika pendek disambung \\ Yang panjang dipotong \\ Yang rumpang disisip.
}

Nan umpang minta di sisik (Nasroen, 1971:40-

Maksud pepatah di atas adalah bagaimana cara memandang tradisi termasuk seni pertunjukan dapat diperbaharui atau dikreasikan, sesuai perkembangan dan disertai pertimbangan etika dan estetika Minangkabau yakni aluajo patuik. Kreativitas yang dilakukan Efyuardi sesuai dengan pandangan Murgiyanto sebagai berikut:

Memelihara tradisi bukanlah sekedar memelihara bentuk tetapi lebih pada jiwa dan semangat atau nilai-nilai. Maka kita akan dengan lebih leluasa bisa melakukan interpretasi dan menciptakan kembali, sekaligus kita juga akan mewarisi sikap kreatif dan imajinasi yang subur sebagaimana dimiliki nenek moyang kita yang telah berhasil menciptakan karya-karya besar di masa lampau. Dengan demikian, kita akan selalu dapat menyelaraskan semangat kesenian tradisi dengan perkembangan kehidupan masyarakat pada masa sekarang (2004:16). 
Materi-materi pertunjukan Simarantang didasari pada penafsiran terhadap kaba. Keberadaan kaba merupakan ruang dengan berbagai kemungkinan estetik yang dipilih Tuo Randai untuk merealisasikan keseluruhan daya kreasinya. Daya kreasi tersebut muncul melalui telaah terhadap penciptaan carito, yang dilakukan dengan menyeleksi kemungkinankemungkinan tafsir yang sudah didapatkan. Kreativitas itulah yang kemudian ditetapkan dalam rencana perancangan pertunjukan Simarantang Karang Manih secara keseluruhan.

Identifikasi kreativitas estetik Efyuhardi dilihat dari posisinya sebagai Tuo Randai di sanggar Simarantang Alam Takambang Maimbau. Berbeda dari sanggar-sanggar Simarantang yang biasa menamakan sanggar Simarantang dengan judul carito yang tak lain adalah nama tokoh utama dalam carito Simarantang dan hanya setia memainkan satu carito Simarantang tersebut. Efyuhardi bersama sanggar ALam Takambang Maimbau justru lebih variatif dalam mengangkat carito pertunjukan Simarantang yang bersumber dari kaba.

Efyuardi dengan latar belakang pengetahuan tradisi dan ilmu teater yang dimilikinya menjadikan Simarantang sebagai wadah kreativitas estetik dengan menata tradisi Simarantang, membangun Simarantang, mengembangkan Simarantang dan mengkreasikannya. Tindak kreatif Efyuhardi tersebut dapat di lihat pada proses penciptaan Simarantang Karang Manih. Aspek-aspek kreativitas Efyuhardi pada penciptaan Simarantang Karang Manih bernaung pada estetika Minangkabau. Estika Minangkabau yang dikenal dengan Alua jo Patuik (alur dengan patuik).

Arzul menjelaskan bahwa arti secara gramatikal kata alua (alur) adalah sesuai dengan prosedur, atau tata cara yang berlaku, kelaziman dalam adat. Kata patuik (patut) adalah kepantasan atau kelaziman sesuatu terletak pada tempatnya. Dengan demikian, kata alua - patuik adalah kesesuaian sesuatu berdasarkan kelaziman, prosedur adat dan terletak pada tempatnya (2014: 38). Alua jo patuik menjadi ukuran dalam menimbang, memutuskan dan bertindak dalam kehidupan masyarakat Minangkabau. Dualisme alua dan patuik harus sejalan agar mendapatkan hasil yang indah, cocok, bagus, baik dan benar. Jika sesuatu hanya alua saja tapi tidak patuik dapat dipastikan akan menimbulkan ketimpangan atau konflik. Sebab alua merujuk pada tata cara, aturan dan hukum. Sementara patuik yang tidak sesuai dengan alua juga akan mendapati ketimpangan dan salah. Sebab yang dikatakan patuik harus memiliki kepantasan atau kelayakan sesuai dengan alua seperti petitih malatakkan sesuatu di tampeknyo (meletakkan sesuatu di tempatnya).

Jika seseorang, masyarakat ataupun suatu lembaga sudah bertindak dengan alua jo patuik maka rasa damai dan tentram akan tercipta. Konsepsi alua jo patuik juga didudukan dalam berkesenian di Minangkabau khususnya Simarantang. Sebab peristiwa Simarantang dan aspek antropologisnya saling berkaitan dan itu terwujud dan tercipta. Secara umum, teater tradisonal juga merupakan transformasi dari antropologi manusia ke dalam sebuah pertunjukan. Proses kreatif Simarantang Karang Manih yang sesuai dengan Alua jo Patuik akan tampak rancak. Kata rancak dapat dipahami secara inderawi yang berarti indah atau bagus dan dipahami secara sifat yang berarti baik atau benar. Dahrizal menyatakan, bahwa definisi rancak adalah nilai berdasarkan Alua jo Patuik terhadap sesuatu yang dapat menimbulkan kesenangan bagi yang merasakannya (wawancara, 20 Januari 2017). Setiap elemen Simarantang yang rancak memiliki prinsip dan kaidah-kaidah dalam proses kreatif Simarantang.

Penilaian dalam sebuah Simarantang terletak pada pemeranan carito, komposisi legaran dan komposisi karawitan yang digarap secara selaras, serasi dan seimbang sesuai estetika Minangkabau agar terlihat rancak. Untuk pencapaian pertunjukan Simarantang Karang Manih yang rancak diperlukan tindak kreatif dalam proses penciptaan Simarantang Karang manih. Tindak kreatif penciptaan Simaratang meliputi kaidah-kaidah berikut.

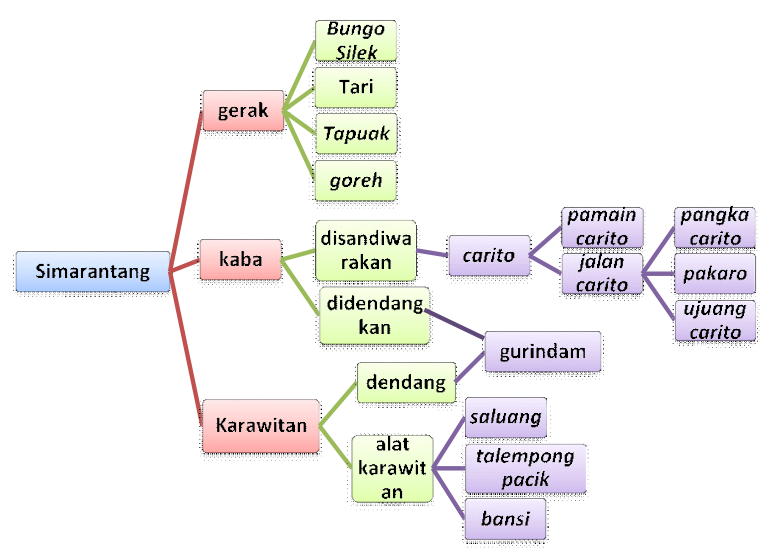

Bagan Aspek - aspek Simarantang Karang Manih Efyuhardi (ilustrasi: Fani DS)

\section{a. Penciptaan Carito}

Karang Manih adalah nama kaba. Kaba merupakan sastra lisan yang tidak diketahui secara jelas pengarangnya. Prinsip dari kaba adalah selalu 


\section{GEEAR Jumal Sai isulya}

menceritakan tentang tokoh yakni manusia sebagai subjek dengan berbagai permasalahannya yang berhubungan dengan masyarakat dan kebudayaannya. Maka dari itu lazim judul dari kaba selalu merupakan nama dari tokoh utama yang terdapat dari kaba tersebut. Kaba Karang Manih disusun oleh Efyuhardi menjadi sebuah carito berupa teks-teks adegan dengan deskriptif naskah pertunjukan yang akan dilakoni pamain carito dan juga harus dipahami pendukung pertunjukan Simarantang Karang Manih lainnya. Teks carito mempermudah sistem latihan Simarantang, agar lebih tertata dalam membangun rancangan struktur pertunjukan. Hal ini tentu jauh lebih efektif dibandingkan cara lama para Tuo Randai dahulunya yang biasa cendrung menjabarkan carito secara tutur kepada pendukung pertunjukan seperti pamain carito, anak randai, dan pamain karawitan.

\section{1) Pamain carito}

Pamain carito adalah orang yang berperan sebagai tokoh yang memainkan carito dengan karakter yang terdapat pada carito Simarantang. Setiap pamain carito memiliki takah. Takah bisa diartikan sebagai bentuk, namun secara luas dapat diartikah sebagai kata perumpamaan yaitu mendekati pengertian kata seperti, kata ibarat, kata laksana dan kata seumpama. Takah adalah imajiner karakter pamain carito yang terdapat didalamnya ciri dan identifikasi pamain carito.

Takah pamain carito Simarantang Karang Manih menurut Efyuhardi adalah a) Karang Manih : tokoh utama carito, gadis berumur 16 tahun, cantik, lemah lembut, sopan dan baik hati. (Kemenakan Datuak Gampo Alam). b) Datuak Gampo Alam: Pria tahun, berumur 50, tegas dan bijaksana. (Mamak Karang Manih dan Malin Parmato, ayah dari Magek Pilihan dan Suami Upiak Ramolah). c) Upiak Ramolah: Wanita berumur 40 tahun, angkuh, pemarah, pandai bermulut manis dan bermuka dua. (Istri Datuak Gampo Alam dan ibu dari Magek Pilihan). d) Magek Pilihan: Pria berusia 18 tahun, angkuh, sombong dan suka berjudi. (Anak dari Datuak Gampo Alam dan Upiak Ramolah). e) Malin Parmato: Pria berusia 20 tahun, baik hati, sopan, pekerja keras dan tampan.(Kakak Karang Manih). f) Upiak Zaitun: Wanita berusia 35 tahun, baik hati dan jujur. (Tetangga). g) Parewa: Pemuda berusia sekitar 20-an tahun, merupakan preman yang suka berjudi, dan bersikap seenaknya (Kawan seperjuadian Magek Pilihan) (wawancara 24 Juni 2016).

Takah harus dipahami oleh seseorang yang akan memainkah tokoh, sebab pamain carito dituntut untuk dapat batakah ${ }^{17}$ kuat. Takah adalah aspek pemeranan Simarantang yang berpegang pada kaba yang dijadikan carito Simarantang. Pamain carito harus mengerti jo nan ampe $k^{18}$ yakni manurun ${ }^{19}$, mandaki ${ }^{20}$, malereng ${ }^{21}$, dan mandata ${ }^{22}$.

\section{2) Jalan Carito}

Jalan carito berarti jalan cerita atau yang disebut juga alua ${ }^{23}$ carito. Kaba yang dikembangkan menjadi penokohan dalam carito dijadikan sebagai dasar penciptaan peristiwa Simarantang kemudian dibentuk menurut jalan carito. Jalan carito menggerakan peristiwa yang dihadapi tokoh utama carito dan dipaparkan menjadi teks. Peristiwa disebut carito jika di dalamnya terdapat pengembangan peristiwa tokoh utama dari pangka carito menjadi pakaro ${ }^{24}$ hingga mencapai ujuang ${ }^{25}$ carito.

Pangka carito adalah persoalan awal yang terkandung dalam lakon Simarantang. Pangka carito dapat mengandung tema carito Simarantang atau secara khusus merupakan ide pokok dari carito Simarantang. Pangka carito menjadi landasan awal dari berkembangnya kreativitas estetik penciptaan Simarantang. Pangka carito merupakan persoalan awal yang dihadapi pamain utama carito.

Pada Simarantang Karang Manih pangka carito berisikan permasalahan awal yang dimiliki Karang Manih yang merupakan tokoh utama. Pangka carito dari Pertunjukan Simarantang Karang Manih adalah Karang Manih yang merupakan yatim piatu dititipkan oleh kakaknya Bujang pamenan pada mamak $^{26}$ Datuak Gampo Alam karena akan pergi merantau. Hal tersebut disambut baik oleh Datuak Gampo Alam namun sebaliknya, istri Datuak Gampo Alam bernama Upiak Ramolah dan anaknya Magek Pilihan tidak menyukai hal tersebut. Karang Manih yang baik budi kerap mendapatkan perlakuan tidak adil dan cacian ketika mamaknya pergi ke ladang.

Pangka carito dikembangkan menjadi pakaro. Pakaro adalah konflik yang di hadapi tokoh utama dalam carito. Pakaro Simarantang Karang Manih yaitu pada saat Magek Pilihan kalah berjudi dan ia hendak mengambil kalung milik Karang Manih, namun Karang Manih menolak dikarenakan kalung tersebut peninggalan almarhum ibunya. Magek Pilihan memaksa Karang Manih sehigga terjadi perseteruan dan didengar oleh Upiak Ramolah. Mendengar jeritan Karang Manih, Upiak Ramolah memarahi Karang Manih dan berpihak pada anaknya Magek Pilihan dan mereka berdua bersekongkol mengusir Karang Manih .

Pakaro akan dikembangkan menjadi ujuang carito. Ujuang carito merupakan pengembangan peristiwa dari pakaro hingga mencapai akhir carito. 
Ujuang carito biasanya berisikan penyelesaian atau akhir dari pakaro. Ujuang carito Simarantang Karang Manih menceritakan tentang selang beberapa bulan kemudian, Bujang Pamenan pulang dari rantau dan hendak menemui adiknya. Saat tiba di rumah Datuak Gampo Alam, ia tidak menjumpai adiknya. Bujang Pamenan dikabari oleh Upiak Ramolah dan Magek Pilihan bahwa Karang Manih minggat dak kerap melakukan tindakan tidak senonoh melanggar norma adat dan agama.

Mendengar hal mato tersebut, Bujang Pamenan tidak mempercayainya dan terjadi perseteruannya dengan Magek Pilihan. Perkelahian Malin Parmato dan Magek Pilihan mengundang khalayak ramai melihat dan kemudian diketahui oleh Datuak Gampo Alam dan melerai perkelahian itu. Datuak Gampo Alam yang sudah terpengaruh dengan Istri dan Anaknya turut menyalahkan Karang Manih dan hampir terjadi perseteruan dengan Bujang Pamenan yang tidak terima mendengar kabar mengenai adik perempuannya

Tak lama kemudian datanglah upiak Zaitun yang mengetengahi dan mengatakan peristiwa sebenarnya dan menyatakan bahwa Karang Manih tidak bersalah. Karang Manih juga tinggal bersamanya. Mendegar hal itu, Datuak Gampo Alam marah besar terhadap istri dan anaknya, dan mengusir meeka berdua karena kejahatannya. Jalan carito Simarantang Karang Manih bersifat linear. Carito Simarantang Karang Manih mempunyai penjabaran peristiwa yang terus menerus maju dari pangka carito menuju pakaro dan sampai pada ujuang carito.

\section{b. Pelatihan}

Pelatihan merupakan proses prapertunjukan Simarantang Karang Manih. Selain berupa metode atau teknis sebelum masuk ke ranah pertunjukan, pelatihan adalah ruang pengenalan dan penerapan nilai-nilai adat dan budaya Pariaman oleh Efyuhardi kepada seluruh pendukung pertunjukan Simarantang Karang Manih. Pendukung pertunjukan meliputi pamain carito, anak randai, dan pamain karawitan yang tak lain adalah anak-anak usia Sekolah Dasar (SD) hingga Sekolah Menengah Umum (SMU). Hal tersebut merupakan daya kreativitas Efyuhardi dalam membangun Simarantang.

Sebelum masuk pada latihan perbagian Simarantang Karang Manih, seluruh pendukung pertunjukan seperti anak randai, pamain carito dan pamain karawitan diberi pemahaman mengenai carito Karang Manih. Langkah awal dengan membahas naskah carito Karang Manih agar bisa dipahami dramatik pertunjukan yang akan di bangun oleh Efyuhardi.

\section{1) Pelatihan Legaran}

Simarantang merupakan teater yang tumbuh dan berkembang dalam masyarakat Minangkabau di Pariaman. Wujud pertunjukan Simarantang berupa formasi melingkar yang disebut legaran. Legaran merupakan konsep latar atau setting dalam peristiwa Simarantang. Legaran berasal dari bahasa Minangkabau yakni dari kata lega yang artinya putar yang diberi imbuhan an yang bermakna artinya putaran.

Sebelum terciptanya Simarantang, legaran sudah ada sebagai gerak-gerak indah dalam pola melingkar yang disebut randai. Atraksi gerak-gerak indah dari silat dengan pencapaian sekelompok orang yang tak mesti berakhir di laga. Dahulunya legaran dilatih sepanjang malam di halaman surau selepas sholat Isya. Legaran dalam Simarantang dikenal juga dengan sebutan balabe $k^{27}$ sebab setiap pergantian adegan selalu diawali dengan gerakan ini. Gerakan legaran merupakan penggabungan bungo silek, tari dan tapuak yang disertai goreh sebagai unsur permainan dan keindahan. Komposisi gerak legaran juga disertai dendang dan alat karawitan Minangkabau. Unsur-unsur legaran yang digarap dengan rampak dan variatif akan menjadikan pertunjukan Simarantang menarik dan memukau penonton.

Legaran terbagi dua posisi yakni disebut legaran tagak dan legaran duduak. Legaran tagak adalah posisi anak randai berdiri dengan gerak balega ${ }^{28}$ di dalam legaran dengan fungsi sebagai peralihan adegan. Sementara itu, legaran dengan posisi anak randai duduk dengan fungsi sebagai lattar dalam Simarantang yang disebut legaran. Legaran bergerak membentuk lingkaran cincin. Selama tokoh berdialog, pemain legaran duduk diposisi lingkaran cincin tersebut lalu kembali berdiri memainkan beberapa tapuak, gerak tari dan bungo silek sambil berjalan mengikuti lingkaran sebagai bentuk pergantian adegan. Pada saat ini gerakan pemain legaran disertai dendang sebagai narasi cerita.

Gerak dalam legaran disertai goreh, tapuak, tari, dan bungo silek akan membuat pertunjukan menarik. Legaran tidak bisa dipisahkan dari Simarantang sebab merupakan batang dari pertunjukan. Simarantang tidak bisa dikatakan Simarantang jika tidak memiliki legaran. Tanpa legaran sebuah pertunjukan teater tradisonal Minangkabau ini hanya sama hal nya dengan sandiwara atau drama lainnya. Legaran Simarantang Karang Manih dibentuk 


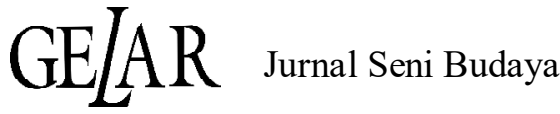

oleh anak randai yang berjumlah 16 orang dan diantaranya terdapat 3 orang tukang goreh sebagai pemberi goreh secara bergantian. Hal ini mempertimbangkan stamina dan menjaga keseimbangan gerak dalam legaran.

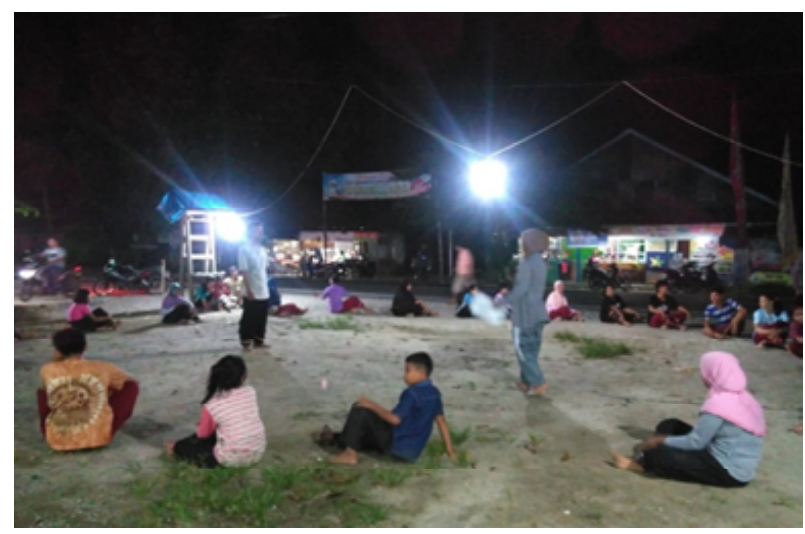

Gambar Legaran duduak sebagai latar atau setting sebagai tempat peristiwa dan adegan Simarantang (Foto: Fani DS).

Seorang tukang goreh harus memiliki kemampuan melebihi anak randai lainnya. Seorang tukang goreh harus memahami jalan carito yang dibawakan, kepekaan terhadap gerakan dan memahami dendang sebagai patokan dari gerakan yang akan dilakukan. Goreh selalu mempertimbangkan panjang gerakan yang disesuaikan dengan dendang. Kelantangan suara sangat diutamakan bagi seorang tukang goreh, dikarenakan seorang tukang goreh harus memberi goreh kepada anak randai lainnya ketika memulai suatu gerakan. Goreh yang diucapkan tukang goreh pada setiap gerak tapuak maupun gerak tari disertai dengan kata-kata Apzzz!! Hep, tah, tih ,yaa!! Untuk memulai suatu gerakan tukang goreh terkadang memariasikan gerak dengan tapuak sebagai pengganti teriakan. Untuk gerakan rampak dengan durasi yang panjang, tukang goreh sering menggunakan teriakan panjang dan keras seperti kata yaa!! untuk mengakhiri gerakan tersebut.

Tukang goreh mempunyai peran yang sangat penting dalam memberi goreh melalui teriakan seperti "Assh!!". Teriakan tersebut berfungsi sebagai tanda dimulainya suatu gerakan, karena pada hakikatnya gerak pada pertunjukan Simarantang memakai sistem rampak. Untuk mewujudkan gerak rampak perlu adanya suatu komunikasi yang dilakukan antar anak randai dalam pertunjukan Simarantang. Goreh berfungsi membentuk komunikasi sehingga kesatuan gerak dalam legaran tetap rampak.
Legaran dibentuk dengan pola lantai tunggal yakni berbentuk lingkaran. Hal mendasar dari pelatihan legaran adalah latihan gerak dengan membuat gerakan pencak adopsi dari bungo silek. Bungo silek gerak legaran carito Karang Manih, tampak menekankan gerakan Luambek dan silek sitaralak. Luambek adalah seni yang khas mengandung muatan lokal sosial budaya Pariaman dengan ciri khas, ialah menciptakan gerak yang bersumber dari Alqur'an dan Hadist serta alam yang diproyeksikan menjadi gerak yang dinamis. Dalam Alqur'an dan Hadist serta alam terdapat empat perkara, yaitu larangan, suruhan, sabar, dan perintah. Berdasarkan sifat penghulu yang demikian, maka ada empat hal yang membentuk gerak bela diri sehingga setiap gerak berisi larangan, suruhan, sabar, atau perintah. Hal tesebut jelas dilihat dari gerak langkah pasti namun perlahan dengan gerak tangan yang disertai gerak ujung-ujung jari. Selain itu bungo silek yang digunakan adopsi silek yang terkenal di Pariaman yaitu silek sitaralak. Hal ini bisa dilihat dari langkah, tangkok ${ }^{29}$, bukak ${ }^{30}$, kambang tangan ${ }^{31}$ dan menahan. Gerak inti dari gerak silek sitaralak bermakna hubungan silaturahmi.

Gerak legaran Simarantang Karang Manih juga adopsi dari gerak tari galombang dan tari bagurau. Asas tari galombang sangat terlihat pada legaran tagak dengan sikap kaki dan tangan, yang disebut dengan kudo-kudo ${ }^{32}$, gelek ${ }^{33}$, siku-siku $u^{34}$, ambek ${ }^{35}$, tapuak. Pergerakan kaki dikenal dengan langkah duo ${ }^{36}$ dan langkah tigo $^{37}$, dan langkah ampek ${ }^{38}$. Keindahannya terlihat jika semua penari serempak bergerak tinggi kemudian merendah, sambil maju dan mundur dengan perlahan, seperti gelombang air laut.

Asas tari bagurau merupakah tarian yang biasa dilakukan oleh orang-orang sepergaulan yang sedang bekerja bersama-sama dengan berdendang bergantian. tujuan bagurau adalah untuk bergurau atau berkelakar dengan tema-tema meliputi: keluh-kesah, kedukaan, sindiran, ajakan, suka ria dan rayuan. Spirit tari bagurau terlihat dalam gerak legaran yang harus selaras dengan dendang. Adapun anak randai ikut mengulang dendang kalimat terakhir disetiap bait yang didendangkan tukang dendang sambil terus bergerak dalam legaran. Untuk itu anak randaijuga tau dengan seluruh dendang yang dibawakan tukang dendang agar sesuai antara gerakan dan dendang.

Anak randai bergerak sesuai tanda goreh dari tukang goreh dalam legaran Simarantang Karang Manih. Gerak dalam legaran mengikuti gerak tukang goreh yang dianggap sebagai pemimpin legaran. Gerakan tukang goreh ditiru oleh anak randai lainnya berdasarkan goreh Appzz..! Tah... Tih... Yaa..! Variasi 
gerak dilakukan dalam berbagai bentuk pengembangan gerak rampak seperti tapuak tangan, tapuak galembong, dan petik jari.

\section{2) Pelatihan Pamain Carito}

Pamain carito merupakan orang yang bermain peran menghidupkan carito Simarantang. Proses latihan Simarantang memiliki teknik pemeranan yang harus dikuasai oleh pamain carito. Tokoh harus sesuai dengan peristiwa yang dijadikan carito, bukan tokoh berdasarkan naskah yang sudah ada. Pamain carito dengan sendirinya tidak sekedar harus menguasai aspek-aspek pertunjukan Simarantang, tetapi juga harus mampu menerjemahkan secara tuntas gagasangagasan dasar yang tersirat dalam kaba. Kaba sebagai titik tolak carito yang melandasi wujud pertunjukan Simarantang.

Proses latihan dalam Simarantang Karang Manih pada dasarnya menempatkan aspek pamain carito sabagai bidang kerja yang penting. Seluruh jalinan materi-materi pertunjukan, baik yang bersifat visual maupun auditif sangat dipengaruhi oleh sentuhan esensi silek dari pamain carito dan pemahaman kato nan ampek. Silek adalah dasar dari pemeranan pamain carito. Dahrizal mengenai tiga esensi silek pada Simarantang yang harus dimiliki oleh pamain carito yakni silek kato, silek parasaan dan silek fisik (Wawancara Juli 2016).

\section{a) Silek Kato}

Silek kato adalah pengucapan kata-kata pamain carito atau bisa disebur basilek lidah ${ }^{39}$. Aksi reaksi pamain carito dalam bakato ${ }^{40}$ disebut Silek kato atau dapat dipahami sebagai dialog. Silek kato dalam Simarantang Karang Manih yakni menggunakan bahasa Minangkabau.

Efyuhardi menyebutkan prinsip bahasa Minangkabau dalam satu kalimat adalah Sembilan suku kata. Sembilan suku kata merupakan yang paling bagus dan baik untuk silek kato dan isi dendang, meski dalam bakato bisa dipakai delapan, Sembilan dan sepuluh suku kata (wawancara, 1 September 2015). Hal ini dapat dilihat pada penggalan silek kato Bujang Pamenan di Simarantang Karang Manih pemeran Bujang Pamenan berikut.

Ma-mak- kan-duang -di-ba-dan-di-ri,

$\begin{array}{lllllllll}1 & 2 & 3 & 4 & 5 & 6 & 7 & 8 & 9 \\ \text { Mang-ko- } \text { am-bo- } \text { da-tang-ka-ma-ri, } \\ \begin{array}{cccccccccc}1 & 2 & 3 & 4 & 5 & 6 & 7 & 8 & 9\end{array}\end{array}$

Da-nga-kan- nan- am-bo-sam-pai-kan,

$\begin{array}{lllllllll}1 & 2 & 3 & 4 & 5 & 6 & 7 & 8 & 9\end{array}$

Di-ha-ri nan-sa-pa-gi-nang-ko,

$\begin{array}{lllllllll}1 & 2 & 3 & 4 & 5 & 6 & 7 & 8 & 9\end{array}$

De-nai-mam-ba-ri-ta-hu-ma-mak,

$\begin{array}{lllllllll}1 & 2 & 3 & 4 & 5 & 6 & 7 & 8 & 9\end{array}$

Ba-so-nyo-de-nai- ka-ma-ran-tau,

$\begin{array}{lllllllll}1 & 2 & 3 & 4 & 5 & 6 & 7 & 8 & 9\end{array}$

lyo-ka-ra-nah- in-do-pu-ro,

$\begin{array}{llllllll}1 & 2 & 3 & 4 & 5 & 6 & 7 & 8\end{array}$

Un-tuang - mu-jua su-ra-tan hi-duik,

$\begin{array}{lllllllll}1 & 2 & 3 & 4 & 5 & 6 & 7 & 8 & 9\end{array}$

Mam-baok-ba-keh-ka-kam-puang-nang-ko

$\begin{array}{llllllll}1 & 23 & 4 & 5 & 6 & 7 & 8 & 9\end{array}$

Setiap pamain carito Karang Manih dilatih untuk mampu dan harus bakato dengan pola ucap delapan, sembilan dan sepuluh suku kata kecuali parewa. Parewa adalah pamain carito yang biasanya hadir dalam adegan-adegan parodi dan komedi dalam Simarantang. Parewa lebih sering menggunakan bahasa keseharian atau lebih dikenal dengan kato mandata (kata mendatar) yang diberlakukan pada orang yang se-usia. Parewa biasanya lazim batakah preman kampung, suka buat onar, dan suka berjudi. Parewa dalam Simarantang Karang manih berjumlah tiga orang. tiga orang ini cendrung dilatih improvisatoris ${ }^{41}$ untuk membangun komedi dan diutamakan lebih berinteraktif dengan penonton Simarantang Karang Manih.

b) Silek Perasaan

Silek parasaan merupakan wujud ekpresi yang mewakili perasaan dan emosi dari suasana hati pamain carito. Silek parasaan terkait dengan gaya, mimik dan olah rasa yang lahir dari respon terhadap lawan main. Efyuhardi menyebutkan Pamain carito Simarantang Karang Manih harus melakukan pendekatan empiris terhadap situasi yang dialami tokoh agar mampu mewakili takah tokoh Simarantang Karang Manih (wawancara, September 2015).

c) Silek Fisik

Silek fisik maksunya adalah aksi reaksi gerak atau laku pamain carito yang didasari dari silek kato dan silek parasaan. Selain itu pada silek fisik juga menekankan pada cakak yang artinya perkelahian. Pertunjukan Simarantang Karang Manih ada bagian perkelahian sebagai unjuk kemampuan seni beladiri dari suatu nagari. Silek fisik merupakan salah satu bagian yang menarik dan ditunggu oleh penonton Simarantang. 


\section{GEEAR Jumal Sai isulyaa}

Ketiga esensi silek ini merupakan kaidah-kaidah yang harus dikuasai seorang pamain carito agar tampak rancak. Kecakapan pamain carito dalam kato, parasaan dan fisik menjadi kunci dasar dari kemampuan pamain carito. Pada silek kato dibutuhkan kecerdasan dalam berkata-kata, silek perasasan membutuhkan kepekaan dan sensitivitas dalam mewujudkan laku dan silek fisik membutuhkan ketangkasan dalam bergerak. Tiga lakuan ini harus sesuai dengan alua jo patuik yakni kato nan ampek dengan mempertimbangkan lawan main di dalam carito Simarantang Karang Manih.

\section{3) Pelatihan Karawitan}

Pelatihan karawitan pada Simarantang Karang Manih, mencakup pada wilayah bunyi-bunyian yang di komposisikan selaras, serasi dan seimbang dengan menggunakan raso yang terdapat dalam carito Karang Manih. Bunyi-bunyian yang dimaksud tidak hanya berasal dari alat kerawitan, namun juga dari gurindam, kreasi gerak berupa tapuak yang disertai goreh. Bunyibunyian ini di dapat dikreasikan sesuai dengan suasana carito. Sesuai dengan ungkapan adat Saciok bak ayam, sadantiang bak basi. Maksudnya antara sesuatu yang harus sejalan atau selaras. Maka dari itu pelatihan karawitan dalam Simarantang Karang Manih diperlukan diskusi seluruh pendukung Simarantang Karang Manih dalam menentukan bunyibunyian yang mendukung suasana carito termasuk di dalamnya dendang. Tapi lebih spesifiknya latihan karawitan merujuk pada penggunaan alat-alat karawitan dan dendang.

Kehidupan budaya masyarakat Pariaman, dapat tercermin dari silek kato Simarantang, baik dialog yang diucapkan yang penuh dengan pantun dan syair serta prosa liris yang berupa untaian bait yang masing-masing bait umumnya terdiri dari empat baris, dua baris berisi sampiran, sedangkan dua lainnya berisi maksud yang sebenarnya. Hal tersebut tampak dalam proses penciptaan Simarantang Karang Manih yang ditata. Efyuhardi menyadari perlunya bait-bait tersebut untuk menjaga irama-irama pertunjukkan agar sesuai dengan Alua jo Patuik. Karena sifatnya yang liris, terikat dengan jumlah suku kata dan adanya sajak, syair, dan pantun. Kaba didramakan dan juga didendangkan. Di dalam Simarantang bagian-bagian kaba didramakan menjadi silek kato dan yang didendangkan disebut gurindam.

Efyuhardi menyebutkan, bahwa dendang dapat dibagi menjadi empat jenis. Pertama dendang ratok yaitu dendang yang berisikan ratapan, sedih atau menghiba-iba. Kedua dendang gembira yaitu dendang suka ria tentang kesenangan dan bahagia. Ketiga Dendang indang adalah dendang yang bersahutsahutan yang berisikan pituah adat dan iramanya mengikuti irama dendang tari indang. Keempat dendang salawaik merupakan dendang yang berisikan dzikir dan salawat atas nabi.

Adapun alat karawitan yang digunakan dalam pertunjukan Simarantang Karang Manih yaitu saluang ${ }^{42}$, bansi ${ }^{43}$ dan talempong pacik ${ }^{44}$ (terdiri dari gandang, talempong dan sarunai). Saluang dan bansi digunakan dalam mengiring dialog dan dendang. Talempong pacik digunakan dalam penyemarak suasana atau sebagai pemanggil khalayak. Beragam dendang berkembang di Minangkabau yang bisa digunakan dalam pertunjukan Simarantang Karang Manih. Setiap dendang dipilih sesuai dengan alua carito Simarantang Karang Manih.

Efyuhardi mengungkapkan ada tiga buah dendang yang harus dibawakan dalam pertunjukan Simarantang. Tiga buah dendang ini, sudah menjadi konvensi wajib atau ketentuan yang disepakati oleh para Tuo Randai ketika penjurian Festival Randai Minangkabau di Sumatera Barat (wawancara, 1 September 2015). Tiga dendang wajib tersebut diantaranya adalah dendang dayang daini, dendang simarantang randah dan dendang simarantang tinggi. Dendang dayang daini merupakan dendang pembukaan yang berisikan kata persembahan dan sambutan kepada niniak mamak atau pemimpin adat dan penonton Simarantang keseluruhan. Dendang simarantang randah merupakan dendang pengisi legaran pertama, sementara dendang simarantang tinggi adalah dendang penutup atau terakhir.

Dendang pada Simarantang Karang Manih berfungsi dalam pergantian adegan, mengisi suasana gerak dengan irama vocal yang bisa disertai dengan alunan karawitan. Dendang dapat menjadi pembatas atau selingan antara adegan yang satu dengan adegan selanjutnya. Dendang dapat menjadi pengatur langkah gerak anak randai yang dikomandoi tukang goreh. Dendang Simarantang Karang Manih berupa gurindam dengan irama A-B-A-B.

Seorang anak randai harus sangat hafal dengan setiap dendang yang digunakan dalam satu pertunjukan Simarantang karena kode yang akan diberikan tukang goreh harus sesuai dengan dari tukang dendang. Anak randai di pertunjukan Simarantang Karang Manih tidak hanya berfungsi untuk menampilkan seni gerak saja, akan tetapi dalam beberapa bagian pertunjukan anak randai melantunkan pengulangan dendang yang disampaikan oleh tukang dendang dengan cara bersama-sama. Begitu juga 
tukang dendang harus dapat melantunkan dendang yang telah di tetapkan tanpa merubah batang dari irama melodi tersebut. Kaba yang didendangkan dalam suatu pertunjukan Simarantang memiliki bentuk melodis yang mengandung unsur-unsur ritmis di dalamnya. Berikut alur dendang Simarantang Karang Manih.

\section{4) Pertunjukan Simarantang Karang Manih}

Pertunjukan Simarantang Karang Manih ditampilkan sebagai hiburan dalam acara alek nagari Kanagarian Sicincin Kabupaten Padang Pariaman pada tanggal 5 September 2015. Pertunjukan digarap dengan durasi 1 jam 20 menit, perihal tersebut dapat dikatakan pertunjukan Simarantang Karang Manih tergolong singkat dibandingkan dengan pertunjukan Simarantang tradisi yang biasa dipertunjukan selama beberapa malam berturut-turut. Efyuhardi menyebutkan pertunjukan Simarantang Karang Manih merupakan rangkaian acara terakhir dan dianggap acara puncak dari alek nagari karena sangat ditunggu oleh masyarakatnya (wawancara, 5 september 2015). Hal ini dapat dilihat dari apresiasi masyarakat yang bertahan hadir untuk menyaksikan Simarantang hingga akhir pertunjukan. Meski malam telah larut dan pementasan baru bisa di mulai menjelang pukul 02.15 WIB. Sebelumnya ada beberapa penampilan seni budaya seperti tari randai, indang dan sebagainya.

Bunyi talempong pacik membuka pertunjukan Simarantang Karang Manih. Anak randai yang berjumlah 16 orang masuk ke arena pertunjukan memainkan tapuak tangan disertai goreh dan berbanjar 2 baris dengan posisi saling berhadapan. Setiap baris terdiri dari 8 anak randai yang terus tapuak tangan sampai talempong pacik berhenti berbunyi. Dayang daini didendangkan, anak randai serempak melakukan gerakan bungo silek dengan tujuan sembah pada Allah dan salam kepada niniak mamak serta penonton yang hadir seraya mengulang dendang disetiap kalimat terakhir dari bait dendang. Sesekali tampak gerak jari-jari tangan anak randai mengisi setiap pencak yang khas adopsi dari seni luambek serta diselingi tapuak galembong. Dendang berganti bunyian talempong pacik, anak randai bergerak rampak membentuk formasi lingkaran dipandu goreh dan akhirnya duduk. Tuo Randai masuk ke tengah legaran duduak memberi kata persembahan dan kembali keluar legaran setelah kata persembahan berakhir.

Talempong pacik kembali berbunyi, seruan goreh mulai mengatur gerakan agar anak randai kembali berdiri. Anak randai beraksi dengan tapuak tangan dan tapuak galembong serta melangkah kecil mengelilingi formasi searah jarum jam. Simarantang randah kemudian didendangkan dengan iringan saluang dan anak randai kembalibergerak hingga dendang Simarang randah berakhir dan, berganti bunyi talempong pacik. Anak randai melangkah kecil searah jarum jam menunggu goreh, kemudian goreh diteriakkan tukang goreh. Anak randai kembali bergerak atraktif maju dan keluar legaran sambil tapuak tangan dan tapuak galembong sampai akhirnya anak randai kembali membentuk legaran duduak.

Legaran duduak adalah tanda akan dimulainya adegan. Pamain carito masuk ke tengah legaran dan mulai menjalankan carito sesuai takah masing-masing yang sudah diatur dalam pelatihan pamain carito. Legaran duduak adalah saat bagi pamain carito berperan dengan keahlian silek kato, silek parasaan dan silek fisik yang didukung bunyibunyian alat kerawitan untuk menciptakan suasana. Sementara anak randai istirahat dan tetap berada di formasi lingkaran, namun tidak terikat dengan adegan yang terjadi di tengah legaran. Anak randai boleh saja duduk santai dan ikut menjadi penonton pertunjukan, atau anak randai dan penonton juga bisa saja merespon peritiwa yang sedang berlangsung untuk mendukung carito.

Saat adegan berakhir akan disambut oleh bunyi iringan talempong pacik, kemudian anak randai berdiri dan bergerak mengikuti goreh membentuk legaran tagak. Saat legaran tagak anak randai kembali aktiv bergerak dengan rampak lengkap beserta bungo silek, tari dan tapuak mengikuti goreh seperti sebelumnya. Saat tukang dendang mulai berdendang, anak randai menari selaras dengan irama dendang yang diiringi alunan bansi atau saluang dan anak randai juga selalu mengulang kalimat terakhir dari bait dendang yang dibawakan tukang dendang.

Setiap legaran tagak memiliki variasi gerak yang berbeda merujuk pada dendang yang dibawakan tukang dendang. Variasi gerak disesuaikan dengan jumlah legaran yang akan dipertunjukan sebagai pengantar adegan agar pertunjukan lebih semarak dan atraktif. Setelah dendang di setiap legaran berakhir, anak randai akan kembali melangkah mengitari pola legaran dan melangkah maju serempak sembari tapuak tangan kemudian melangkah keluar kembali sembari atraksi tapuak galembong hingga tukang goreh meneriakan goreh tanda mengakhiri gerakan dan anak randai kembali pada legaran duduk. Adegan selanjutnya akan di mulai, begitu seterusnya hingga legaran terakhir yang ditutup dengan dendang Simarantang Tinggi. 


\section{GE[AR surmal saim iublya}

\section{c. Kesimpulan}

Tulisan ini pada dasarnya menjelaskan aspekaspek teater rakyat di Pariaman, yang disebut Simarantang. Penjelasan tulisan ini terfokus sebagaimana tertera pada judul "Alua jo Patuik Proses Kreatif Simarantang Karang Manih Efyuhardi”. Simarantang memiliki kaidah-kaidah estetika yang khas sebagai produk budaya masyarakat melalui kreativitas seorang Tuo Randai. Hal ini dapat dilihat dari tindak kreatif Efyuhardi dalam penciptaan Simarantang Karang Manih. Tindak kreatif Efyuhardi pada penciptaan Simarantang Karang Manih bernaung pada estetika Minangkabau yaitu Alua jo Patuik. Kreativitas penciptaan Simarantang yang sesuai dengan Alua jo Patuik akan dikatakan rancak. Kata rancak dapat dipahami secara inderawi yang berarti indah atau bagus dan dipahami secara sifat yang berarti baik atau benar. Setiap aspek Simarantang yang rancak memiliki kaidah-kaidah dalam proses kreatif Simarantang. Adapun prinsip dan kaidah-kaidah dalam penciptaan Simarantang Karang Manih dapat dilihat pada proses kreatifnya yaitu penciptaan carito, pelatihan sampai pada pertunjukan Karang Manih.

\section{Catatan Akhir:}

1 Tuo Randai adalah adalah pimpinan dalam proses kreatif pertunjukan Simarantang, dituakan bukan berdasarkan umur, tapi berdasarkan pemahamannya terhadap Simarantang dan kewibawaannya dalam memimpin kelompok.

${ }^{2} P e m e n a n$ anak nagari adalah bentuk kreativitas yang berjalan seiring perkembangan masyarakat hingga menjadikannya populer dan diminati di daerahnya.

${ }^{3}$ Carito adalah pengertian dari cerita atau lakon.

${ }^{4}$ Pamain carito adalah orang yang memainkan carito.

${ }^{5}$ Kanagarian adalah kesatuan wilayah budaya yang dilaksanakan secara demokratis dan bersifat federal (memiliki otonomi untuk menentukan kebijaksanaan pada wilayahnya sendiri) dalam tatanan budaya Minangkabau, dipimpin oleh seorang wali, yang disebut Wali Nagari. Pemerintah Indonesia memadankannya dengan keberadaan desa dalam sistem kepemerintahan saat ini.

${ }^{6}$ Pamain curito adalah pemain cerita atau sama dengan aktor.

${ }^{7}$ Randai yang dimaksud adalah pemahaman masyarakat pariaman yaitu, seni pertunjukan berupa tari dengan formasi melingkar dan belum ada unsure cerita di dalamnya

${ }^{8} /$ ndang adalah tarian tradisional daerah pariaman yang berisikan syair dan pantun dalam mengiringi gerakan yang disertai kecepatan tangan, tarian ini dimainkan secara duduk satu saf sama seperti tari saman dari aceh, namun penari disertai rapa'i yang dipukul secara serentak.

${ }^{9}$ Luambek adalah kesenian Pariaman yang berupa gerakan yang berasal dari gerakan silat yang mana ada aturan khusus dalam pementasannya.

${ }^{10}$ Pamain carito adalah orang yang memainkan tokoh dalam cerita Simarantang.

${ }^{11}$ Pamenan anak nagari artinya kesenangan suatu muda-mudi di suatu nagari atau desa, biasanya merupakan kesenian ataupun permainan rakyat.

${ }^{12}$ Anak randai adalah pemain randai yang bergerak dalam legaran Simarantang.

${ }^{13}$ Silek lidah artinya silat lidah atau kemampuan berbicara dan berkata-kata.

14 Tingkah adalah variasi pola dalam satu permainan.

${ }^{15}$ Tapuak galembong adalah gerakan memukul celana galembong yang merupakan celana khusus untuk anak randai yang memiliki pisak datar disertai tepuk tangan dengan tingkah dan motif tertentu sesuai dengan suasana ilustrasi cerita.

${ }^{16}$ Pisak merupakan bagian bawah paha dari celana.

${ }^{17}$ Batakah artinya berkarakter.

${ }^{18}$ Kato nan ampek adalah empat bahagian mengenai cara berprilaku atau sopan santun baik berupa cara berbahasa dan bersikap menurut lawan bicara.

${ }^{19}$ Kato manurun adalah cara berbahasa dan bersikap kepada yang lebih muda.

${ }^{20}$ Kato mandaki adalah cara berbahasa dan bersikap kepada yang lebih tua.

${ }^{21}$ Kato malereng adalah cara bersikap dan kepada hubungan menantu dengan mertua, ipar dan sebaliknya.

${ }^{22}$ Kato mandata adalah cara bersikap dan berbahasa kepada sesama besar.

${ }^{23}$ Alua artinya dalam bahasa Indonesia adalah alur (jalan cerita) atau disebut juga dengan plot.

${ }^{24}$ Pakaro artinya dalam bahasa Indonesia adalah perkara,dapat dikatakan pokok permasalahan atau konflik.

${ }^{25}$ Ujuang carito artinya dalam bahasa Indonesia adalah ujung cerita atau akhir dari cerita yang biasanya berisikan penyelesaian masalah.

${ }^{26}$ Mamak adalah saudara laki-laki dari ibu 
${ }^{27}$ Balabek adalah salah satu gerakan silat yakni bergerak dalam lingkaran dengan sikap siaga dengan koordinasi tangan dan kaki yang siap menghadapi serangan.

${ }^{28}$ Balega artinya berlegaran atau berkeliling.

${ }^{29}$ Tangkok artinya tangkap yakni gerakan menangkap serangan lawan baik serangan tangan atau kaki.

${ }^{30} \mathrm{Bukak}$ artinya buka yani upaya melepaskan kuncian dan ikatan lawan.

${ }^{31} \mathrm{Kambang}$ tangan artinya mengembangkan tangan atau merentangkan tangan.

${ }^{32} \mathrm{Kudo}-k u d o$ adalah kuda-kuda yang artinya sikap berdiri dengan kedua kaki yang terbentang lebar menahan berat tubuh.

${ }^{33}$ Gelek adalah gerakan menghindari serangan lawan dengan tidak merunah posisi kaki tapi hanya merubah posisi badan dari lurus ke miring.

${ }^{34}$ Siku-siku adalah adalah gerakan menyiku atau menggerakan siku-siku tangan untuk menangkis serangan lawan.

${ }^{35} \mathrm{Ambe} k$ adalah gerakan menghambat serangan lawan.

${ }^{36}$ Duo artinya dua

${ }^{37}$ Tigo artinya tiga

${ }^{38}$ Ampek artinya empat

${ }^{39}$ Basilek lidah artinya bersilat lidah atau kemampuan bercakap-cakap.

${ }^{40}$ Bakato artinya berbicara atau berkata-kata.

${ }^{41}$ Improvisatoris adalah teknis pemeranan dengan kemampuan improvisasi.

${ }^{42}$ Saluang adalah alat musik tiup Minangkabau yang terbuat dari talang dengan empat lubang. Panjang saluang kira-kira $40-60 \mathrm{~cm}$, dengan diameter 3-4 cm.
${ }^{43}$ Bansi adalah Alat musik tiup Minangkabau dengan tujuh lubang yang terbuat dari talang denga panjang kira-kira 33,5-33,6 cm dengan diameter 2,5-3 $\mathrm{cm}$.

${ }^{44}$ Talempong pacik adalah Suatu jenis kesenian berbentuk ensambel telempong.

\section{KEPUSTAKAAN}

Arzul, "Nilai-nilai Pendidikan Karakter Dalam Randai Bujang Sampai di Nagari Gunuang Rajo Kecamatan Batipuah Kabupaten Tanah Datar". Padang: Disertasi Studi IImu Pendidikan Program Pascasarjana Universitas Negeri Padang, 2014.

Harun, Chairul. Kesenian Tradisi di Minangkabau. Jakarta: Proyek Pembinaan Media Kebudayaan Ditjen Kebudayaan, Mendikbud, 1922.

Murgiyanto, Sal. Tradisi dan Inovasi. Jakarta: Widya Sastra, 2004.

Nasroen. Dasar Falsafah Adat Minangkabau. Jakarta: Bulan Bintang, 1971.

Panghoeloe, Rasyid Manggis Dt Radjo. Kaluak Randai. Jakarta: Proyek Penerbitan Buku Sastra Indonesia dan Daerah, 1980.

Soedarsono. "Garap Tari Nusantara 1 (makalah mata kuliah Pascasarjana S2)". Surakarta: Institut Seni Indonesia Surakarta, 2006. 